Maurer School of Law: Indiana University

Digital Repository @ Maurer Law

2015

\title{
Respecting Intent and Dispelling Stereotypes by Reducing Unintended Pregnancy
}

Dawn E. Johnsen

Indiana University Maurer School of Law, djohnsen@indiana.edu

Follow this and additional works at: https://www.repository.law.indiana.edu/facpub

Part of the Law and Gender Commons, Medical Jurisprudence Commons, and the Women's Health Commons

\section{Recommended Citation}

Johnsen, Dawn E., "Respecting Intent and Dispelling Stereotypes by Reducing Unintended Pregnancy" (2015). Articles by Maurer Faculty. 2516.

https://www.repository.law.indiana.edu/facpub/2516

This Article is brought to you for free and open access by the Faculty Scholarship at Digital Repository @ Maurer Law. It has been accepted for inclusion in Articles by Maurer Faculty by an authorized administrator of Digital Repository @ Maurer Law. For more information, please contact rvaughan@indiana.edu. 


\section{Respecting Intent and Dispelling Stereotypes by Reducing Unintended Pregnancy}

Dawn Johnsen

\section{Introduction}

In "Expectant Fathers, Abortion, and Embryos," Dara Purvis considers the interests of "expectational fathers," as she calls them, in the related contexts of abortion and the disposition of pre-embryos in assisted reproductive technologies (ART). ${ }^{1}$ Her thought-provoking essay contributes to a subject - men and reproductive decision-making - that is too little studied. I embrace her emphasis on respect for both men's equal role in parenting and women's right to decide whether to terminate or continue pregnancy. In this Comment, I examine her central concern that abortion discourse promotes harmful gender stereotypes by minimizing expectational fathers' interests. I suggest that Purvis's own analytic focus on intent, properly applied and extended, actually ameliorates her concern and points instead to a more direct, unapologetic acknowledgement of men's (and women's) desires to avoid parenthood in particular circumstances and at particular times in their lives.

For most individuals, avoidance of parenthood is fully consistent with loving and shared parenthood of existing or future children; most men and women desire parenthood, but not as a result of every act of sexual intercourse. Policies that empower men and women to avoid unintended pregnancy are the sensible, win-win, front-line approach to addressing disputes over abortion between expectational fathers and women.

\section{Intent and Stereotypes}

Purvis's principal concern centers on the related concepts of intent and gender stereotypes. She generally supports a more robust role for intent in resolving ART disputes ${ }^{2}$ and worries that adding abortion to the analysis may undermine that position: "[I]f some of the rhetoric debating abortion rights minimizes the expectational parental interest of men, does that rhetoric work at cross-purposes to...application of intentbased rules in other contexts?"3 Similarly, Purvis posits that abortion discourse unfairly portrays men as uninterested in childbearing, which in turn perpetuates gender stereotypes about women. She cites in particular abortion opponents' contention that men should have the right to avoid parental responsibility because women have the right to decide whether to continue the pregnancy: "By turning from narratives of men saddened by abortion, who had hoped to become fathers, and focusing on unwilling fathers whose parental investment was limited to sending

Dawn Johnsen, J.D., is the Walter W. Foskett Professor at Indiana University Maurer School of Law, where she teaches constitutional law. 
checks, abortion critics reinforce the...perception of men as uninvested in children...."

One relatively minor point regarding Purvis's assertion that abortion opponents bear responsibility for a harmful minimization of expectational fathers' interests: I suspect that advocates who oppose child support obligations when women continue pregnancies against men's wishes are largely distinct from abor- enthood at the time of sexual intercourse. As Purvis discusses, however, there is no succinct analogue to "pregnant woman" to describe a man who would be the genetic father of a child who would be born to a woman if she decides to continue a pregnancy and successfully carries to term (fifteen to twenty percent of known pregnancies end in miscarriage). This full description is quite cumbersome, which reflects the complexity of the potential relationship.

Second, regarding stereotypes: Purvis certainly is correct that governmental actors and ordinary citizens alike should be vigilant against the pernicious, often unconscious influences of gender stereotypes on issues of pregnancy and childrearing. Judges, for example, sometimes confuse biological difference and social construct, including by conflating childbearing and childrearing. ${ }^{7}$ However, far from promoting harmful stereotypes, acknowledging that in most instances

tion opponents who would compel all women to continue pregnancies. There may be some overlap in the groups, but the arguments clearly are distinct. Roe $v$. $W_{a d e}{ }^{5}$ actually has been cited to support the argument that men's relative lack of control of parenthood should relieve men of financial liability. Conversely, many who oppose abortion on the view that life begins at conception would recognize that allowing men to avoid child support would be counterproductive to their anti-abortion goals.

More fundamentally, I question Purvis's central assumption that prevailing abortion discourse inappropriately minimizes the interests of expectational fathers, either to the detriment of the proper role of intent or the advancement of stereotypes. First, as to intent: an accurate portrayal of men's lack of interest in parenting in the context of abortion decisions need not adversely affect the role intent should play in ART disputes for the simple reason that intent plays a fundamentally different role in the two contexts. When a man and a woman decide to employ ART, it is with the intent and for the purpose of having a child. Parenthood is the desired outcome. Disputes that arise about pre-embryo disposition typically result from changed circumstances. In sharp contrast, the vast majority of abortions follow from a pregnancy that neither party intended; relatively few result from changed circumstances. ${ }^{6}$

In fact, use of the phrase "expectational fathers" in the context of abortion, although a clear improvement over "father" alone, is far from ideal because typically neither party will have had an expectation of parneither men nor women want a child to result from a particular act of sexual intercourse is vital to effective public policy. A more complete understanding of the realities of pregnancy, childbearing, and abortion points to policies that address - indeed, preempt abortion disputes by reducing unintended pregnancy.

\section{Non-Procreative Sex and Intentional Parenthood}

A desire to engage in sexual intercourse without risking parenthood is not a wholesale rejection of parenthood, by men or women. It is, quite simply, a sentiment shared at some point by almost all people who have sexual intercourse with opposite sex partners. Those same individuals also typically desire parenthood not as a potential result of every heterosexual encounter, but at a time and with a partner of their choosing. Virtually all American women who have sex with men use contraception at some point in their lives. ${ }^{8}$ Eightyfive percent of women and seventy-six percent of men will have a child by age forty. ${ }^{9}$ An estimated three in ten women will have an abortion in their long reproductive lifetimes, but those same women bear children and are mothers..$^{10}$ Contrary to stereotypes, most women who have abortions are mothers: Sixty-one percent have at least one child, and thirty-four percent have two or more children. ${ }^{11}$ In one study, nearly four in ten women cited among the reasons for having an abortion that they had completed their childbearing, and almost one-third said that they were not ready to have a child. ${ }^{12}$ 
The unintended pregnancy rate in the United States is extraordinarily high at half of all pregnancies, amounting to more than three million a year; about forty percent of women decide to terminate and sixty percent decide to continue an unintended pregnancy. ${ }^{13}$ Where the decision is contrary to men's wishes, men suffer a real and consequential loss of procreative control. In the cases where abortion results, a man may suffer emotional distress from the loss of a desired child or the belief that abortion is the moral equivalent of killing a person. When a woman chooses to continue an unintended pregnancy, the course of a man's life can be greatly altered by unplanned parenthood, particularly if the woman is not his chosen life partner. Although the responsible and legally mandated course is to pay child support and be a loving father, we should not deny the complexity and costs of this real-world situation. outside of marriage, the forced notification requirement touched only about one percent of expectational fathers. ${ }^{16}$ The impact on those women, however, often would have been devastating. The Casey Court explained, "In well-functioning marriages, spouses discuss important intimate decisions such as whether to bear a child. But there are millions of women in this country who are the victims of regular physical and psychological abuse at the hands of their husbands."17 Battering, which can include marital rape, can escalate with news of a pregnancy and also may extend to the couple's children. "[T] he primary reason women do not notify their husbands is that the husband and wife are experiencing marital difficulties, often accompanied by incidents of violence."18

Attempts to restrict abortion have escalated in recent years, but given Casey's strong holding against mandated husband notification, restrictions have

\section{As the four Justices dissenting in Hobby Lobby noted, however, an IUD can cost up to a month's salary for an employee earning minimum wage and struggling to provide for a family. Our nation accrues enormous benefits - including the avoidance of abortion disputes between women and expectational fathers - by assisting women and men in their efforts to time the birth of children for when they are best able to bear and care for them.}

\section{The Supreme Court on Men and Abortion}

The U.S. Supreme Court captured much of this when it first addressed the issue of government-mandated husband consent to abortion in 1976. A husband has a "deep and proper concern and interest...in his wife's pregnancy," but "when the wife and husband disagree on this decision, the view of only one...can prevail." The Court held that the woman must prevail because "it is the woman who physically bears the child and who is the more directly and immediately affected by the pregnancy."14 In its second and most recent decision on the issue, Planned Parenthood v. Casey, the Supreme Court in 1992 helped dispel some important stereotypes about the nature of such disputes. ${ }^{15}$ Casey is best known for its five-four partial reaffirmation of Roe $v$. Wade, but the outcome was mixed: the Court upheld some challenged provisions in a Pennsylvania law, but held unconstitutional a requirement that a woman notify her husband before obtaining an abortion.

As the Court explained, the vast majority of women (about ninety-five percent) voluntarily involve their husbands in abortion decisions. Given these voluntary consultations and the incidence of pregnancy taken other forms, usually aimed at shutting down providers of abortion services. ${ }^{19}$ Before Casey, however, the anti-abortion movement sought to create a test case to overrule Roe through the dissemination of a "Fathers' Rights Litigation Kit."20 The sample proceedings in the "kit" sparked lawsuits by men seeking to block women's abortions, until the Supreme Court made clear it would not take such a case. ${ }^{21}$ I served as co-counsel representing those women, who suffered harassment, privacy intrusions, and delays until courts vindicated their rights; those cases, too, involved dysfunctional, sometimes abusive relationships. Again, the men who have sought to enlist the force of government to compel childbirth - or to avoid child support payments - are not representative of the vast majority of men, who work out difficult decisions and disagreements in the context of personal relationships.

\section{Conclusion}

This extension of Purvis's focus on intent points to the vital role government plays in empowering women and men to avoid unintended pregnancy. The rate of unintended pregnancy in the United States is substantially higher than in other developed nations, ${ }^{22}$ 
with rates highest among economically disadvantaged women. ${ }^{23}$ A typical American woman wishing to have only two children must spend three decades avoiding the ten or more unintended pregnancies that would result absent effective contraception. ${ }^{24}$ The Affordable Care Act as implemented by the Obama Administration took a vital step toward filling unmet need by including contraception among the health care provided at no additional cost under covered insurance plans. Notwithstanding the Supreme Court's 2014 Hobby Lobby decision allowing certain employers to act upon religious beliefs to deprive their employees of this valuable benefit, ${ }^{25}$ most health plans will make available effective contraceptive methods that otherwise might not have been affordable. For example, the hormonal intrauterine device (IUD) is forty-five times more effective than oral contraceptives and ninety times more effective than condoms, based on typical use. ${ }^{26}$ As the four Justices dissenting in Hobby Lobby noted, however, an IUD can cost up to a month's salary for an employee earning minimum wage and struggling to provide for a family. ${ }^{27}$ Our nation accrues enormous benefits - including the avoidance of abortion disputes between women and expectational fathers - by assisting women and men in their efforts to time the birth of children for when they are best able to bear and care for them.

\section{References}

1. D. E. Purvis, "Expectant Fathers, Abortion, and Embryos," Journal of Law, Medicine छ Ethics 43, no. 2 (2015): 330-340.

2. D. E. Purvis, "Intended Parents and the Problem of Perspective," Yale Journal of Law छீ Feminism 24, no. 2 (2012): 210-53.

3. See Purvis, supra note 1

4. Id.

5. 410 U.S. 113 (1973).

6. Although estimates are from the perspective of women and hard data is unavailable, by one estimate 95 percent of abortions follow an unintended pregnancy. L. B. Finer and M. R. Zolna, "Unintended pregnancy in the United States: Incidence and Disparities, 2006," Contraception 84, no. 5 (2011): 478-85, at 479 n.4. See also L. B. Finer, L. F. Frohwirth, L. A. Dauphinee, S. Singh, and A. M. Moore, "Reasons U.S. Women Have Abortions: Quantitative and Qualitative Perspectives," Perspectives on Sexual and Reproductive Health 37, no. 3 (2005): 110-18.

7. For example, the Supreme Court split five to four to uphold a law that imposed different citizenship rules for children born abroad depending upon whether the child's mother or father was a U.S. citizen. Nguyen v. INS, 533 U.S. 53 (2001).

8. K. Daniels, W. D. Mosher, and J. Jones, "Contraceptive Methods Women Have Ever Used: United States, 1982-2010," National Health Statistics Report, No. 62 (February 14, 2013): at 8.

9. G. Martinez, K. Daniels, and A. Chandra, "Fertility of Men and Women Aged 15-44 Years in the United States: National Survey of Family Growth, 2006-2010," National Health Statistics Report, No. 51 (April 12, 2012): at 7.

10. R. K. Jones and M. L. Kavanaugh, "Changes in Abortion Rates Between 2000 and 2008 and Lifetime Incidence of Abortions," Obstetrics $\mathcal{E}$ Gynecology 117, no. 6 (2011): 1358-66, at 1366.

11. R. K. Jones, L. B. Finer, and S. Singh, "Characteristics of U.S. Abortion Patients, 2008," Guttmacher Institute (May 2010): at 8.

12. See Finer et al., supra note 6, at 112.

13. L. B. Finer and M. R. Zolna, "Shifts in Intended and Unintended Pregnancies in the United States, 2001-2008," American Journal of Public Health 104, no. S1 (2014): S43-S48, at S44 (counting among intended pregnancies those where women felt indifferent).

14. Planned Parenthood v. Danforth, 428 U.S. 52, 70-71 (1976).

15. 505 U.S. 833 (1992).

16. Id. at 894. See also R. K. Jones, A. M. Moore, and L. F. Frohwirth, "Perceptions of Male Knowledge and Support among U.S. Women Obtaining Abortions," Women's Health Issues 21, no. 2 (2011): 117-23.

17. Casey, 505 U.S. at $892-93$

18. Id. at 892 .

19. E. Nash, R. B. Gold, A. Rowan, G. Rathbun, and Y. Vierboom, "Laws Affecting Reproductive Health and Rights: 2013 State Policy Review," Guttmacher Institute (January 2014), available at <http:/www.guttmacher.org/statecenter/updates/2013/statetrends42013.html $>$ (last visited April 14, 2015).

20. See G. Elsasser, "Court Won't Hear Father's Abortion Appeal," Chicago Tribune, November 15, 1988.

21. See, e.g., Conn v. Conn, 526 N.E.2d 958 (Ind. 1988), cert denied, 488 U.S. 955 (1988); Lewis v. Lerwis, No. 11140 (Mich. Ct. App. Sept. 15, 1988), appeal denied, No. 84149, 1988 Mich. Lexis 1751, at *1 (Mich. Ct. App. Sept. 22, 1988), application for stay denied, 487 U.S. 165 (1988), cert. denied sub nom. Myers v. Lewis, 487 U.S. 165 (1988); Doe v. Smith, 527 N.E.2d 177 (Ind. 1988), applications for stay denied, 486 U.S. 1308 (1988) (Stevens, J., in chambers).

22. S. Singh, G. Sedgh, and R. Hussain, "Unintended Pregnancy: Worldwide Levels, Trends and Outcomes," Studies in Family Planning 41, no. 4 (2010): 241-50, at 244.

23. See Jones et al., supra note 13 , at 5-9.

24. R. B. Gold, A. Sonfield, C. L. Richards, and J. J. Frost, "Next Steps for America's Family Planning Program: Leveraging the Potential of Medicaid and Title X in an Evolving Health Care System," Guttmacher Institute (2009): at 6.

25. Burwell v. Hobby Lobby, 134 S. Ct. 2751 (2014).

26. Brief for the Guttmacher Institute and Professor Sara Rosenbaum as Amici Curiae Supporting the Government, at 4, Hobby Lobby, 134 S. Ct. 2751 (2014)

27. Hobby Lobby, 134 S. Ct., at 2800 (Ginsburg, J., dissenting). 